\title{
Creating a Unique Sustainable Rating System for Saudi Arabia to Achieve Environmental Assessment and 2030 Vision
}

\author{
Wael A. Aboneama ${ }^{1}$
}

\begin{abstract}
Saudi Arabia Vision 2030 is a planning for 15 years that announced in 2016 to make Saudi Arabia's economy more powerful and has multi income channels not only oil, and developing public services. The planning focuses for better life enhancement with creating new economic regions inside the country with huge investments with hundreds of billions of US dollars. Sustainable development in this case is a mandatory to can achieve the goals of this vision. Sustainability is the process of change, in which the exploitation of resources, the direction of investments, the orientation of technological development and institutional change are all in harmony and enhance both current and future potential to meet human needs and aspirations. A unique sustainable rating system for Saudi Arabia environment should be created and applied under the protection of law umbrella to insure applying sustainable principals on all new developments and constructions. This paper focuses on reviewing applied sustainable rating system in Saudi Arabia against the environmental conditions and people culture in this area of the world and redistribute the weights of each item to be more compatible with the environment, local resources, and human needs.
\end{abstract}

Keywords: Sustainable rating system, Saudi Arabia, 2030 Vision.

\section{Introduction}

All over the world, buildings consume $17 \%$ of potable water, $25 \%$ of forest wood, $33 \%$ of carbon dioxide emissions and $40 \%$ of energy consumption and manufactured materials (Candace Say, 2008). That was the reason for the whole wold to start thinking for sustainable development and searching for green buildings, but the assessment method to measure the credibility of applying sustainable criteria on buildings was new issue. Sustainable rating systems are the only reliable method to measure green buildings fig (1).

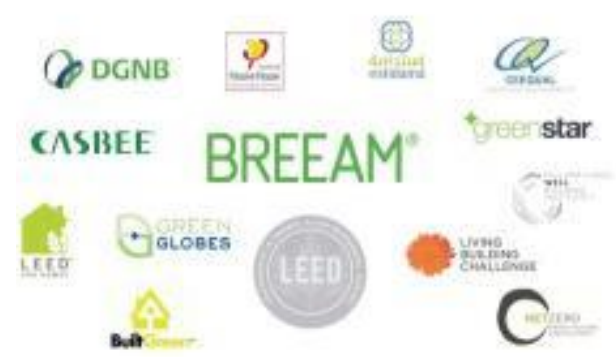

Fig. (1) Sustainability rating systems (James Woodall, 2017) 
BREEAM and LEED, are the most popular green building certification programs used worldwide (wikipedia, 2015). BREEAM is published by the Building Research Establishment (BRE) in 1990 in UK, meanwhile development of LEED began in 1993 in USA. They are the world's longest established method of assessing, rating, and certifying the sustainability of buildings (BREEAM, 2014).

On 25 April 2016, Saudi Arabia leaders announced Saudi Vision 2030 which is a plan to minimize Saudi Arabia's dependence on oil as the only source of energy in the country (Wikipedia, 2016). More than 80 giant projects are planned to be developed and constructed in Saudi Arabia before the year 2030. On 24 Oct 2017 Saudi government announced NEOM project at the Northern West of the country close to the border of Jordan and Egypt. It is a planned to have an area of 26,500 sq $\mathrm{km}$ and it will act as transnational city with estimated budget 500 billion US dollars (Wikipedia, 2018). It is obvious that Saudi Arabia is planning for a great economic and urban development jump. Lack of potable water and renewable energy resources chase this future planning and vision. In the wake of a World Bank report on global water scarcity released in February 2016, various Saudi government officials and water experts warned that the kingdom could run out of water entirely by 2029 if it did not radically reform its agricultural practices and address high water consumption patterns across the country (Ahmed Almansouri, 2017). Fig (2) this statistic shows the total water consumption in Saudi Arabia by region in million cubic meters in 2017. Table (1) describes that the fossil fuels are the most important source of energy in Saudi Arabia which means more carbon dioxide emissions and more pollution and the renewable energy resources don't reflect the real potential in this country.
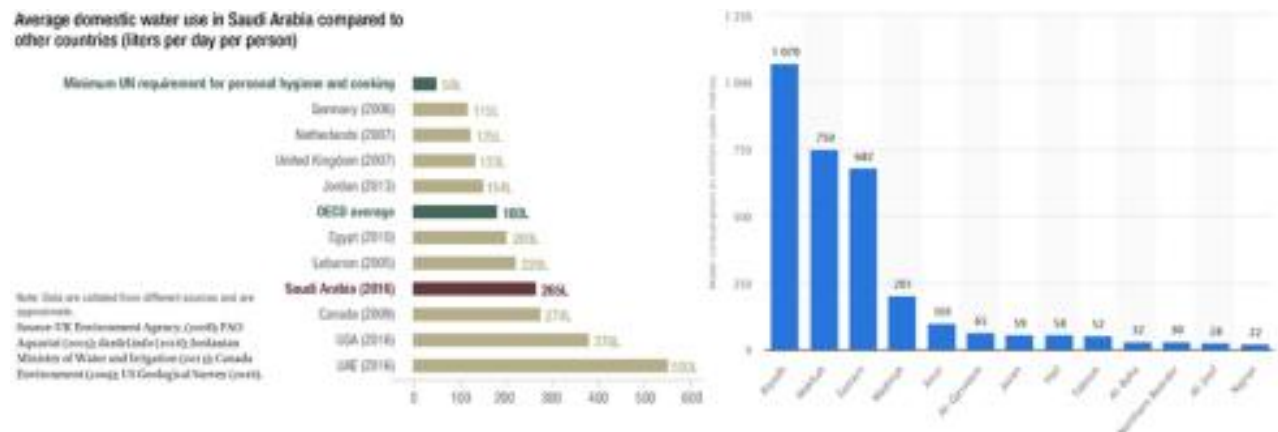

Fig (2) on right describes average domestic water use in Saudi Arabia compared other countries (Abmed Almansouri, 2017), On left water consumption per region in Saudi Arabia (statista, 2018)

Table (1) describes the energy sources in Saudi Arabia compared with Europe in 2014 (saudiarabia/energy-consumption, n.d.)

\begin{tabular}{|c|c|c|c|c|c|}
\hline Energy source & $\begin{array}{r}\text { Total } \\
\text { in Saudi Mrabia } \\
\end{array}$ & $\begin{array}{r}\text { percentage } \\
\text { in Saudi Arabia }\end{array}$ & $\begin{array}{l}\text { percentage } \\
\text { in Europe }\end{array}$ & $\begin{array}{r}\text { per capita } \\
\text { in Sasodi Arabia }\end{array}$ & $\begin{array}{l}\text { per capita } \\
\text { in Europe }\end{array}$ \\
\hline Fassil fuels & 604.27 bn kWh & 99,94 & $43,9 \%$ & $16.722 .24 \mathrm{kWh}$ & $7,954,06 \mathrm{kWh}$ \\
\hline Nuclesr power & $0.00 \mathrm{kWh}$ & $0,0 \mathrm{~s}$ & $7,2 \%$ & $0.00 \mathrm{kWh}$ & $1,265.07 \mathrm{kWh}$ \\
\hline Water power & $0.00 \mathrm{kwh}$ & $0,0 \%$ & $23,4 \%$ & $0.00 \mathrm{kWh}$ & $3,829.91 \mathrm{kWh}$ \\
\hline Renewabie anergy & $604.88 \mathrm{~m} \mathrm{kWh}$ & $0,1 \%$ & $16,2 \%$ & $18.74 \mathrm{kWh}$ & $2,555.34 \mathrm{kWh}$ \\
\hline Other energy seurces & $0.00 \mathrm{kWh}$ & $0,0 \%$ & $4.3 \%$ & $0.00 \mathrm{kWh}$ & $606.17 \mathrm{kWh}$ \\
\hline Totsil produstion capacty & $604.53 \mathrm{bn} \mathrm{kWh}$ & $100,0 \%$ & $160,0 \%$ & $18,740,90 \mathrm{kWh}$ & $16.362 .15 \mathrm{kWh}$ \\
\hline
\end{tabular}


Sustainability in Saudi Arabia is not an option, it is a mandatory to protect the environment for Saudis grandsons' future. Saudi Arabia should work through a strategy, which aims to satisfy development needs of energy. This strategy depends on diversifying energy resources and achieving the most benefit of it besides improving energy devices to enhance the consumption rates. In addition, the strategy should aim also at environmental conservation and improving local manufacturing of energy equipment (Aboneama, Oct. 2015).

\section{Literature Review}

\subsection{Sustainability Rating System}

Sustainability rating systems are created to push all architects, developers, and contractors to protect the environment through their projects by applying the most effective sustainable criteria. Rating systems should be under the protection of law umbrella (Aboneama, Local Rating Systems for Sustainability are Mandatory to Protect the Planet - LEED in the Middle East, 2013).

Table (2) General information of mainstream building rating systems (Mohamed Shaawat, June 2014)

\begin{tabular}{|c|c|c|c|c|c|c|c|c|c|}
\hline $\begin{array}{l}\text { Yame of } \\
\text { System }\end{array}$ & $\begin{array}{c}\text { LFDS } \\
\text { Leadership } \\
\text { in Energy \& } \\
\text { Environment } \\
\text { al Design }\end{array}$ & $\begin{array}{c}\text { G5 } \\
\text { Greea } \\
\text { Star }\end{array}$ & $\begin{array}{l}\text { BREEAM } \\
\text { Building } \\
\text { Research } \\
\text { Esviremiment } \\
\text { Assessment } \\
\text { Methed }\end{array}$ & $\begin{array}{l}\text { CASBEE } \\
\text { Comprehensiv } \\
\text { e Assessment } \\
\text { System for } \\
\text { Burilding } \\
\text { Emvironment } \\
\text { Eificiency }\end{array}$ & $\frac{G G}{\text { Green Globe }}$ & $\begin{array}{c}\text { BCA-GM } \\
\text { BCA-Green } \\
\text { Mark }\end{array}$ & $\begin{array}{c}\text { GSAS } \\
\text { Global } \\
\text { Sustainability } \\
\text { Assessment } \\
\text { System }\end{array}$ & $\begin{array}{l}\text { PBR5 } \\
\text { Pearl } \\
\text { Building } \\
\text { Rating } \\
\text { System }\end{array}$ & $\begin{array}{l}\text { BREEAM-G } \\
\text { BREEAM- } \\
\text { Guir Versiou } \\
\text { (Withdrawn) }\end{array}$ \\
\hline Origin & $\begin{array}{l}\text { United States } \\
\text { of America }\end{array}$ & Australia & $\begin{array}{l}\text { United } \\
\text { Kingdon }\end{array}$ & Jара & $\begin{array}{l}\text { United States } \\
\text { of Amserica }\end{array}$ & Singapore & Quatar & $\begin{array}{l}\text { United } \\
\text { Arab } \\
\text { Emirates }\end{array}$ & $\begin{array}{l}\text { United } \\
\text { Kingitom }\end{array}$ \\
\hline $\begin{array}{c}\text { Managiag } \\
\text { Otganizalion }\end{array}$ & $\begin{array}{l}\text { United Staves } \\
\text { Green } \\
\text { Building } \\
\text { Conucil }\end{array}$ & $\begin{array}{l}\text { Green } \\
\text { Bublding } \\
\text { Conmes } \\
\text { Australia }\end{array}$ & $\begin{array}{l}\text { Buildeng } \\
\text { Research } \\
\text { Establishuient }\end{array}$ & $\begin{array}{l}\text { Japan Ceetn } \\
\text { Buek Council }\end{array}$ & $\begin{array}{c}\text { Grees } \\
\text { Burkling } \\
\text { lnitiative }\end{array}$ & $\begin{array}{l}\text { Buildins \& } \\
\text { Cousmuction } \\
\text { Authority }\end{array}$ & $\begin{array}{c}\text { Gulf } \\
\text { Orghmization } \\
\text { for Reseanch } \\
\text { \& } \\
\text { Deselopment }\end{array}$ & Estimada & $\begin{array}{l}\text { Building } \\
\text { Restarch } \\
\text { Establishment }\end{array}$ \\
\hline Launch Date & 2000 & 2002 & 1990 & 2001 & 2002 & 2005 & 2010 & 2010 & 2008 \\
\hline Ratings & $\begin{array}{l}\text { Certified, } \\
\text { Silver, Gold. } \\
\text { Platimum }\end{array}$ & $\begin{array}{l}1 \text { Star. } \\
2 \text { Star, } \\
3 \text { Star. } \\
4 \text { Star. } \\
5 \text { Star. } \\
6 \text { Star }\end{array}$ & $\begin{array}{l}\text { Pass, Good. } \\
\text { Very Good. } \\
\text { Excellent }\end{array}$ & C, B-, B+, A,S & $\begin{array}{l}1 \mathrm{GG}, 2 \mathrm{GG}, \\
3 \mathrm{GO}, 4 \mathrm{GO}\end{array}$ & $\begin{array}{l}\text { Platimum, } \\
\text { Gold Plus }\end{array}$ & $\begin{array}{l}1 \text { Star, } 2 \text { Star, } \\
3 \text { Star, } 4 \text { Star, } \\
5 \text { Star, } 6 \text { Star }\end{array}$ & $\begin{array}{l}1 \text { Pearl. } \\
2 \text { Pearl. } \\
3 \text { Pearl. } \\
4 \text { Pearl. } \\
5 \text { Pearl. }\end{array}$ & $\begin{array}{l}\text { Pass, Good, } \\
\text { Very Good. } \\
\text { Excellent }\end{array}$ \\
\hline $\begin{array}{l}\text { Arra of } \\
\text { Coverage }\end{array}$ & $\begin{array}{l}\text { Unived Staves } \\
\text { of Amserica }\end{array}$ & Australia & $\begin{array}{l}\text { United } \\
\text { Kingdoun \& } \\
\text { some Erropean } \\
\text { Countries }\end{array}$ & Japain & $\begin{array}{l}\text { Unined States } \\
\text { of Auverica }\end{array}$ & Singepore & Qutar & $\begin{array}{l}\text { United } \\
\text { Arab } \\
\text { Emirates }\end{array}$ & 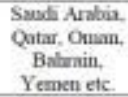 \\
\hline
\end{tabular}

Each rating system developing meets the following principles, table (2):

1. Ensure environmental quality through an accessible, holistic, and balanced measure of environmental impacts.

2. Measuring environmental quality.

3. Quantifying and calibrating a cost-effective performance standard for defining environmental quality.

4. Reflect the social and economic benefits of meeting the environmental objectives covered.

5. Provide a common framework of assessment that is tailored to meet the 'local' context, including regulation, climate, and sector. 


\subsection{Saudi Green Building Forum SGBF \& BREEAM-G}

The Saudi Green Building Forum (SGBF) has become the newest member of USGBC's LEED International Roundtable, which means that Saudi's government realizes the impact of negative behaviors towards the environment and its future's vision and planning. They started to take actions towards sustainability. In addition, they realize the importance of sustainability rating system to ensure the actual practice of sustainable design and construction (Crea, 2017). The question now, if there is any changes on LEED item weights to accommodate the environment of Saudi Arabia? Unfortunately, the answer is no. The LEED certificate issues in Saudi Arabia with the same weights and items of United States however, the environment in both countries are totally different and contradictory.

In 2008, a version called BREEAM-G produced by the British Research Establishment (BRE) for the Arabian Peninsula countries. Unfortunately, this version withdrawn and there is no any data about it for evaluation. Qatar took the step in advance and produced in 2010 its rating system.

The Global Sustainability Assessment System GSAS

The Global Sustainability Assessment System (GSAS) Originally QSAS is a rating system developed for Arabian Peninsula countries. This system was announced after QSAS (Qatar sustainability assessment system) launching.

GSAS is developed after comparison between 40 rating systems all over the world. The most important feature of GSAS is that it takes into account the region's social, economic, environmental and cultural aspects, which are different from other parts of the world. Several countries in the Middle East and North Africa countries called (MENA) region, such as Saudi Arabia, Kuwait, Jordan and Sudan, have shown keen interest in the adoption of GSAS as unified green building code for the region (Zafar, 2017). Unfortunately, for political reasons, it is not used in Saudi Arabia and before any political unrest LEED dominated Saudi construction market.

\subsection{Wind Power in Saudi Arabia}

There are 20 locations in Saudi Arabia that can generate energy from wind. Fig (3) illustrates the potential areas in Saudi Arabia to generate energy and install wind turbines. Results suggest that most of the country can be supported by wind power (Ph.Martin, 20 April 1985).
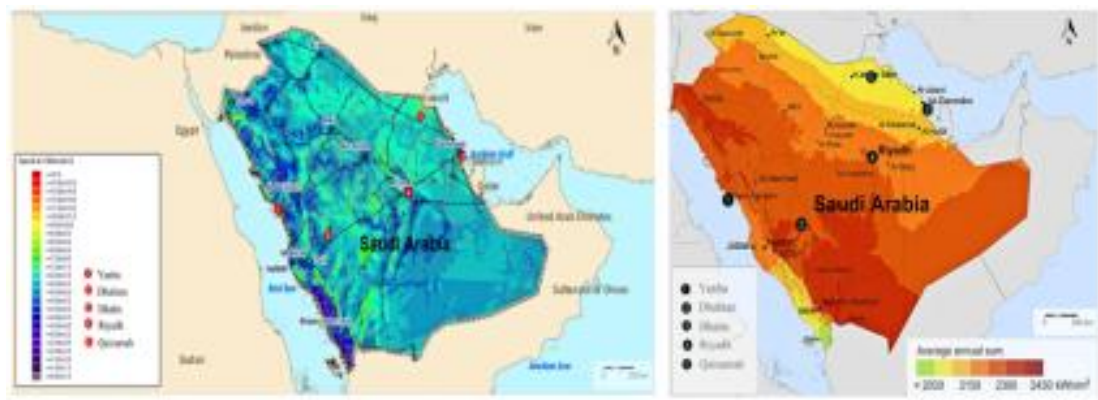

Fig (3) On left wind speed in Saudi Arabia (Mobamed Mohamed, August 2016), On right, solar energy strength (solargis, 2011) 


\subsection{Solar Energy in Saudi Arabia}

Saudi Arabia location is one of the best countries to generate energy from solar radiation because it is located inside the Sun Belt, which has led it to become one of the largest solar energy producers fig (3). Average solar irradiation in Saudi Arabia is about twice as high as in Germany. Average solar irradiation exceeds $1.800 \mathrm{kWh} / \mathrm{m} 2$ up to 2.200 in some locations. The Tabuk area has the highest irradiation. Saudi Arabia also has vast expanses of open desert seemingly tailor-made for solar-panel arrays (Aljamaan, Dec. 2012).

\subsection{Renewable Energy Resources in Saudi Arabia}

Electricity demand in Saudi Arabia increases year and after, which means that energy generation should seek new resources (Saudigazette, 2016). Conventional generation that uses fossil fuels is the reason of pollution and destroying the ecology and human health through carbon and other emissions. It is therefore essential that available renewable resources start power generation. Saudi Arabia can be the largest solar energy producers. (Aljamaan, Dec. 2012). Fig (4) illustrates the potential of generating power from renewable energy in the MENA countries and the actual generated renewable energy from those countries. It is obvious that Saudi Arabia has the third place as available resources but unfortunately listed as last place for actual generated renewable energy.
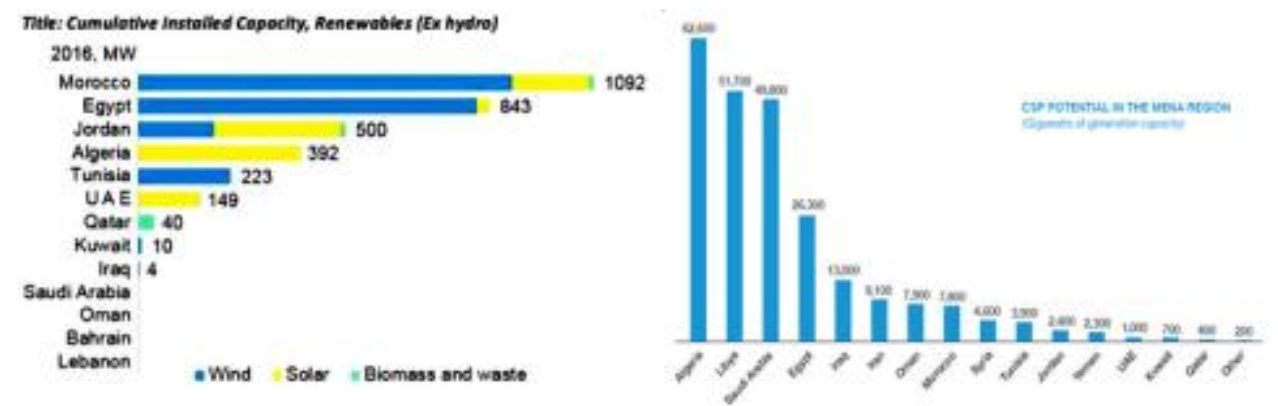

Fig (4) on left renewable energy production (Saudigazette, 2016), on right renewable energy potential in MENA (Aljamaan, Dec. 2012),

\subsection{The Importance of Passive Design in Saudi Arabia}

Saudi Arabia, has one of the warmest weather in the world, which means the air conditioner is turned on day and night. Saudi Arabia uses more than $50 \%$ of its electricity on air conditioning and cooling. Also, desalinate sea water for drinking consume around $20 \%$ of energy. Desalinating sea water is an extremely energy-intensive process, making it very expensive (Schlanger, 2018). All previous data lead to the importance of passive design in Saudi Arabia. It clarifies that the architectural history of the Middle East have abundant techniques for passive and environmental design such as courtyards, mashrabia, takhtaboosh, and orientation techniques. Passive design criteria is focusing on reduction of air-conditioning usage, and moves towards natural lighting and ventilation systems. Trying to achieve or get closer to zero-energy buildings. 


\section{Methodology Steps for Creating a Saudi Arabian Sustainable Rating System}

\subsection{Rating Systems Category Weights}

All sustainable rating systems are based on identical categories fig (5). Each category has certain weight that reflects the actual need for this nation to protect this item according to its environmental requirements (Bsria, 2012). For example, if we build in a place that has lack of water resources. The weight of category called "water efficiency" will be huge to encourage designers, developers, and contractors to use all methods for water saving to can achieve the minimum requirements of this category and that is exactly what we need from them to save our particular environment.

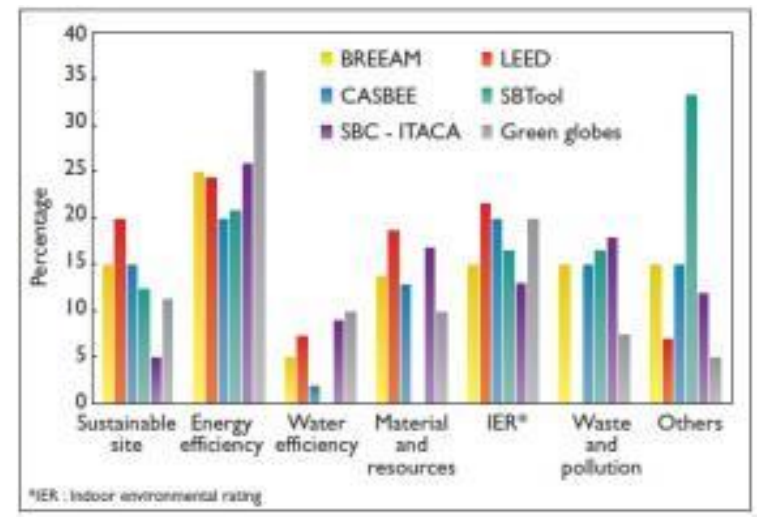

Fig. (5) Comparison between sustainability rating systems weights (Bsria, 2012)

It is obvious that we use the expression of "particular environment". The environmental characteristics and circumstances are totally different from place to place. We never can say that Ohio State has the same environmental conditions as Saudi Arabia. They are totally different. Ohio has a huge amount of rainfall average and forests, on the contrary, Saudi Arabia has lack of potable water resources and most of its lands are desert. Obviously, we can't use rating system category weights from certain environment to protect another one with contradictory conditions. It is like that we feed the horse with gasoline fuel because it is a mean of transportation.

\subsection{Rating System Categories}

All countries share common concerns about their ecology with different weights fig (6). These concerns are the rating systems categories. The global warming, pollution, limited resources and greenhouse gas emissions are the reasons of these categories (Sundus L. Shareef, Nov. 2016). Fig (6) has three different rating systems which are; BREEAM, LEED, and GSAS. They are the most famous in the world. In addition, Saudi Green Building Forum SGBF made an agreements with USGBC, BRE and GSAS. May GSAS is the most closer to the Arabian Peninsula environment because Qatar is in the same Peninsula. But, obviously Saudi Arabia ecology is totally different from UK and USA. In the following we can summarize these categories and the actual need of Saudi Arabia ecology from each one which will be transformed into category weight. 


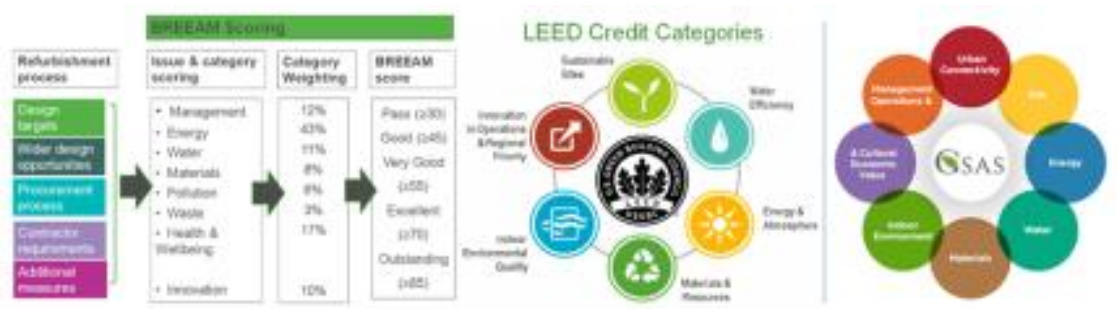

Fig (6) on left BREEAM categories \& weights (BREEAM, 2016), on the middle LEED categories (USGBC, 2010), and on the right GSAS categories (Services/ Green buildings /Why environmental accreditations, 2016)

\subsection{Sustainable Sites}

The sustainable sites category focuses on the environment surrounding the building. Protecting Greenfield and restoring Brownfields are main tasks for this category (USGBC, 2017). It creates a framework that the teamwork should protect ecosystem and minimize carbon emissions and heat islands effect (Sustainablesites, 2015). This category helps to reduce water demand, filter and reduce storm water runoff, provide wildlife habitat, reduce energy consumption, improve air quality, improve human health and increase outdoor recreation opportunities. Saudi Arabian rating system can give 10\% of category weights to the sustainable sites. The following items are the main divisions of sustainable sites and their importance for Saudi Arabia environment:

o Construction activity pollution prevention; the same weight for any place in the world

o Site assessment (it differs from place to another inside the same country)

o Site development - protect or restore habitat (it differs from place to another inside the same country)

o Open space (it depends on each country's culture)

o Rainwater management (it differs from place to another inside the same country)

o Heat island reduction (it is very important for hot countries like Saudi Arabia)

o Light pollution reduction (the same weight for any place in the world)

\subsection{Location and Transportation}

Sustainable projects users should find means of transportation with less carbon emissions and environmental friendly. It is obvious that moving Saudi Arabia to the level of sustainable development with minimizing depending on fossil fuel is restricted to minimize using private car as the main mean of transportation. There are several items should be assessed to ensure this category (USGBC, 2018). This category should have $20 \%$ of category weights.

o Neighborhood Development location

o Sustainable means of transportation (it is a major item with high score of points)

o High priority site

o Surrounding density and diverse uses

o Access to quality transit

o Bicycle facilities (it is difficult item to be applied in very hot weather countries. The research recommend to eliminate this item)

o Reduced parking footprint

o Green vehicles (it is a major item with high score of points) 


\subsection{Water Efficiency}

The Water Efficiency category concerns about water in everything, looking at indoor use, outdoor use, and metering. The category is based on efficiency to save water consumption (USGBC, 2018). As a result, each prerequisite looks at water efficiency and reductions in potable water use alone. Then, the points additionally recognize the use of non-potable and alternative sources of water. This category should have at least $20 \%$ of the weight of Saudi rating system as a result of lack resources for potable water. The points will be distributed on the following items;

o Outdoor water use reduction

o Indoor water use reduction

o Building-level water metering

o Cooling tower water use

\subsection{Energy and Atmosphere}

The Energy and atmosphere category focuses on energy in two perspectives which are; reducing energy consumption and using renewable energy sources (USGBC, 2018). The sector of atmosphere is responsible about avoiding the use of harmful components for the planet atmosphere such as refrigerants. Fig (4) clarifies that Saudi Arabia does not produce energy from renewable resources meanwhile it has one of the highest potential to produce this kind of energy. It means this category should have at least $25 \%$ of the total weights.

o Optimize energy performance

o Building-level energy metering

o Renewable energy production (at least $20 \%$ of the total rating systems weights)

o Fundamental refrigerant management

\subsection{Passive Design}

The indoor environmental quality category aims to enhance indoor air quality, thermal and visual comfort, and occupants' satisfaction (USGBC, 2018). Passive design is one of the most important categories for hot weather and desert countries. The only way to reduce air condition use is following design techniques in the history of architecture in all Middle East countries. In the past, they had the ability to produce comfortable buildings which are existing nowadays without using any kind of energy consumption. It is not an overstatement to say that, historical buildings like (Bayt Al-Suhaymi in Cairo) and more are the real zero-energy buildings with high indoor environmental quality.

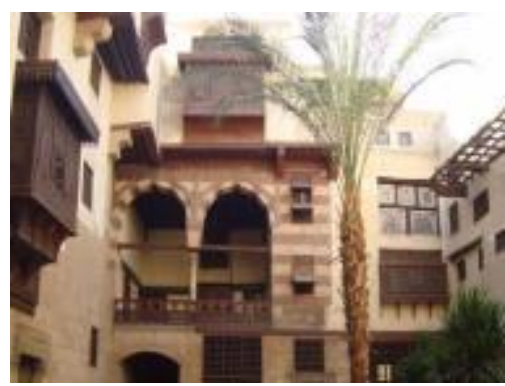

Fig. (7) Bayt Al-Suhaymi (Al-gammal, 2017) 
During last five decades a great leap in construction happened in Saudi Arabia with importing building types from cold weather countries with full of glazed façade that increased energy consumption for cooling and don't respect people culture. This category in Saudi Arabian rating system should has at least 18\% of the total weights. The following items are the main items for passive design category;

o Enhanced indoor air quality strategies

o Thermal comfort

o Interior lighting

o Daylight and quality views

\subsection{Material and Resources}

Reduce, reuse, and recycle are the main critical component of this category. Clearly, reducing consumption is critical, and reusing and recycling waste are important strategies (USGBC, 2018). The total weight of this category should not exceed $7 \%$ of the total weight.

\section{Results and Findings}

We can conclude from this research that we have an excellent opportunity to encourage architects, developers, and contractors to think work and behave in actual sustainable way with creating a unique rating system for Saudi Arabia. The number of certified buildings in Saudi Arabia clarifies the desire of sustainable buildings. In addition, Saudi vision 2030 and NEOM project elucidate the intension of the government for a grand economic and sustainable development step.

\section{Discussion and Analysis}

Creating sustainable rating system for Saudi Arabia will be focused on studying the actual challenges that facing its ecology and its supplies of energy and potable water. Importing one of the rating systems of cold weather and high rainfall average countries gives ostensible results and does not match environmental needs. Calculating rating system categories weight is the most important task to produce a real rating that reflect ecology and country requirements.

\section{Conclusion and Recommendations}

Most of the sustainable rating systems have similarities in categories definition more than differences. Each category has different weight from country to another based on each one environmental needs. This is due to the fact that all of these systems are trying to help us create a better world and leave our children a better and cleaner world (Altın, Jan. 2016). It will be a waste of efforts to use certain rating system that reflects the requirements for cold weather country and full of forests due to high rainfall average in a hot weather country which is full of desert like Saudi Arabia. If it is mandatory to use one of the rating systems all over the world, we should search for a similar environmental requirements like countries inside the Arabian Peninsula and apply their 
rating systems.

In conclusion, creating a unique rating system for Saudi Arabia will be the best choice. Emphasizing on the weights of generating renewable energy, saving water consumption, using passive design techniques to minimize using air-conditioner, and installing means of sustainable transportation are the actual reflection of Saudi Arabia ecology and future needs.

\section{References}

Aboneama, W. (2013). Local Rating Systems for Sustainability are Mandatory to Protect the Planet - LEED in the Middle East. The center of environment behavious studies (cE-Bs), Faculty of architecture, planning, \& surveying, Universiti teknologi, Mara, Malaysia, 83-99.

Aboneama, W. (Oct. 2015). Applying the new sustainable urban development towards the location of the renewable energy resources in Egypt. Wind power North Africa, Discus upcoming wind projectsand how to drive growth in north African wind power market (pp. 2-3). Cairo: IQPC.

Ahmed Almansouri, F. d. (2017, April 4). Saudi-Arabia-water-resources. Retrieved from revolve-water.com: http://www.revolve-water.com/saudi-arabia-water-resources/

Al-gammal, E. (2017, May 22). بيب السحبيسى مرة العدارة الإساحية Retrieved from 3ain.net: http://www.3ain.net/Article/14522/http://www.3ain.net/Article/14522/

Aljamaan, H. (Dec. 2012). The Importance of Solar Energy in Saudi Arabia. Stanford University.

Altın, M. (Jan. 2016). Green Building Rating Systems in Sustainable Architecture. Chapter 43.

BREEAM. (2014, May 8). Why choose BREEAM? Retrieved from breeam.com: https://www.breeam.com/discover/why-choose-breeam/

BREEAM. (2016, Feb 29). scoring_and_rating. Retrieved from breeam.com: http://www.breeam.com/domrefurbmanual/content/03scoring/01scoring_and_rating.htm

Bsria. (2012, May). Rating environmental assessments. Retrieved from bsria.co.uk: https://www.bsria.co.uk/news/article/rating-environmental-assessments/

Candace Say, A. W. (2008). Sustainable rating systems around the world. CTUBUH, Issue II.

Crea, J. (2017, March 20). Saudi Green Building Forum joins LEED International Roundtable. Retrieved from usgbc.org: https://www.usgbc.org/articles/saudi-green-building-forum-joins-leed-internationalroundtable

James Woodall. (2017, Nov 27). Evolution of Green Building Rating Systems: A New Frontier? Retrieved from james-woodall.com: https://www.james-woodall.com/blog/

Mohamed Mohamed, A. E. (August 2016). PSO-Based smart grid application for sizing and optimization of hybrid renewable energy systems. Plos one.

Mohamed Shaawat, R. J. (June 2014). A guide to environmental building rating system for construction of new buildings in Saudi Arabia. Emirates Journal for Engineering Research, 47-56.

Ph.Martin. (20 April 1985). Wind power potential of Saudi Arabia. Solar \& Wind Technology, 139-142.

saudi-arabia/energy-consumption. (n.d.). Retrieved from World Data: https://www.worlddata.info/asia/saudiarabia/energy-consumption.php

Saudigazette. (2016, Dec. 21). Middle East renewable energy potential bright. Retrieved from saudigazette.com.sa: http://saudigazette.com.sa/article/522681/BUSINESS/Middle-East-renewable-energy-potentialbright

Schlanger, Z. (2018, May 22). 70\% of Saudi Arabia's electricity is used for air conditioning. Retrieved from qz.com: https://qz.com/1284239/70-of-saudi-arabias-electricity-is-used-for-air-conditioning/

Services/ Green buildings /Why environmental accreditations. (2016). Retrieved from pacte-ingenierie.com: http://www.pacte-ingenierie.com/index_coeur.php?rub_name=Green-building\&lien=20\&id=0

solargis. (2011). Africa \& Middle East Solar Insolation Map. Retrieved from hotspotenergy.com: http:/ /www.hotspotenergy.com/DC-air-conditioner/solar-map-africa-middle-east.php

statista. (2018, May). saudi-arabia-water-consumption-by-region. Retrieved from statista.com: https://www.statista.com/statistics/627146/saudi-arabia-water-consumption-by-region/

Sundus L. Shareef, H. A. (Nov. 2016). Building sustainability rating systems in the Middle East. Engineering Sustainability, 1-11. 
Sustainablesites. (2015). certification-guide. Retrieved from sustainablesites.org/: http://www.sustainablesites.org/certification-guide

USGBC. (2010). LEED-Credit-Categories. Retrieved from igbc.ie: https://www.igbc.ie/wpcontent/uploads/2014/11/LEED-Credit-Categories.png

USGBC. (2017). sustainable-sites. Retrieved from usgbc.org: https://www.usgbc.org/credits/newconstruction/v4/sustainable-sites

USGBC. (2018). energy-atmosphere. Retrieved from usgbc.org: https://www.usgbc.org/credits/newconstruction/v4/energy-\%26-atmosphere

USGBC. (2018). green-building-101-sustainable-materials-and-resources. Retrieved from usgbc.org: https://www.usgbc.org/articles/green-building-101-sustainable-materials-and-resources

USGBC. (2018). indoor-environmental-quality. Retrieved from usgbc.org: https://www.usgbc.org/credits/existing-buildings/v4/indoor-environmental-quality

USGBC. (2018). location-transportation. Retrieved from usgbc.org: https://www.usgbc.org/credits/newconstruction/v4/location- $\% 26$-transportation

USGBC. (2018). water-efficiency. Retrieved from usgbc.org: https://www.usgbc.org/credits/healthcare/v4/water-efficiency

wikipedia. (2015, April 15). Leadership_in_Energy_and_Environmental_Design. Retrieved from en.wikipedia.org: https://en.wikipedia.org/wiki/Leadership_in_Energy_and_Environmental_Design

Wikipedia. (2016, May 1). Saudi_Vision_2030. Retrieved from en.wikipedia.org: https://en.wikipedia.org/wiki/Saudi_Vision_2030

Wikipedia. (2018, June 5). Neom. Retrieved from en.wikipedia.or: https://en.wikipedia.org/wiki/Neom

Zafar, S. (2017, March 4). Green Building Rating Systems in MENA. Retrieved from ecomena.org: https://www.ecomena.org/green-building-mena/ 